\title{
Results of implementation of the Energy Efficient Quarter program in the pilot territory
}

\author{
Ruslan Minnullin ${ }^{1 *}$, Marina Barbarskaya ${ }^{2}$, Natalia Solopova ${ }^{3}$, and Artem Tsirin ${ }^{4}$ \\ ${ }^{1}$ Industrial University of Tyumen, Volodarskogo St., 38, Tyumen, 625000, Russia \\ ${ }^{2}$ Samara State Technical University, Molodogvardeyskaya str. 244, Samara, Russia \\ ${ }^{3}$ Moscow State University of Civil Engineering (National Research University), Yaroslavskoye \\ Shosse, 26, Moscow, Russia \\ ${ }^{4}$ Institute of Legislation and Comparative Law under the Government of the Russian Federation, \\ Cheremushkinskaya str., 34, Moscow, Russia
}

\begin{abstract}
In Russia, a large number of the state projects of programs of energy saving and increase in energy efficiency is implemented. It is possible to consider the Energy Efficient Quarter program implemented in several cities of Russia as one of such projects. In this article, the results of implementation of this program in the city of Tyumen in the pilot territory are described. The content of actions, the estimated indicators and costs for the implementation of these actions are specified
\end{abstract}

\section{Introduction}

In the modern world, energy is the basis for the development of basic industries that determine the progress of social production. In all industrialized countries, the pace of energy development has outpaced the pace of development of other industries.

Despite the factors of the negative impact of energy on the environment, the increase in energy consumption did not cause particular alarm among general public, as it was clear how this effect could be reduced from technical point of view. This continued until the mid70 s of the last century, when experts had in their hands numerous data indicating a strong anthropogenic pressure on the climate system, which poses a threat of global catastrophe with an uncontrolled increase in energy consumption [1].

Since then, no other scientific issue has attracted such close attention as the issue of real, and in particular, upcoming climate change. It is believed that the main reason for this change is energy, and energy means any area of human activity related to the production and consumption of energy.

However, a correct analysis of the issue of upcoming climate changes and their consequences is possible only with all the factors taken into account. At the same time, undoubtedly, it is necessary to bring maximum clarity to the question of how global energy consumption will be changed in the near future, whether humanity should establish strict self-restrictions in energy consumption in order to avoid a catastrophe of global warming.

* Corresponding author: minnullin400@yandex.ru 
The generally accepted classification divides the sources of primary energy into commercial and non-commercial. The global energy industry as a whole throughout the entire industrial phase of the development of society is based primarily on commercial energy resources. Although it should be noted that there is a whole group of countries (equatorial zone of Africa, Southeast Asia), whose large population maintains its existence almost exclusively at the expense of non-commercial energy sources [2].

Energy saving - implementation of legal, organizational, scientific, industrial, technical and economic measures aimed at the efficient (rational) use (including economical use) of fuel and energy resources and the involvement of renewable energy sources in the economic turnover. Energy saving is an important task for conservation of natural resources.

Currently, household energy saving, as well as energy saving in the field of housing and communal services are the most pressing. The main obstacle to its implementation is to restrain the growth of tariffs for the population for certain types of resources (electricity, gas), lack of funds from utilities for energy saving programs, a low proportion of calculations for individual metering devices and the application of standards, as well as the lack of mass culture of household energy saving.

Efficient use of energy, or "fifth type of fuel" - the use of less energy to provide the same level of energy supply of buildings or technological processes in production.

Unlike energy saving, mainly aimed at reducing energy consumption, energy efficiency is a useful (efficient) energy expenditure [3,4].

International cooperation in the field of energy efficiency is one of the important directions in the activities of the Ministry of Energy of Russian Federation. In the implementation of a number of energy saving and energy efficiency projects, advanced experience of developed countries is already used, and achievements in the field of energy efficiency are also taken into account when forming the basic documents in this field. Thus, the energy dialogue between Russia and EU members since 2000 provides for cooperation in a number of areas, including in the field of energy efficiency. As part of the activities of the Thematic Group on Energy Efficiency, there is a continuous exchange of information and experience in the areas that are part of the Energy Efficiency Initiative. Memorandums and declarations on cooperation in the field of energy efficiency are also concluded with the relevant ministries of France, Italy, Japan, the Netherlands, Denmark, and the United Kingdom $[5,6]$.

In addition to international cooperation in Russia, a large number of government projects on energy saving and energy efficiency programs are being implemented. The Energy Efficiency Quarter program implemented in several cities of Russia can be attributed to one of such projects, which is included in the list of priority areas for improving energy efficiency [7].

\section{Methods}

The purpose of the pilot project "Energy Efficient Quarter" is to work out the organizational, legal and financial-economic measures in the field of energy savings in the residential and social facilities of the city.

In the city of Tyumen in Russia, activities are being developed and carried out as a part of implementation of the comprehensive program "Energy Efficient City".

Implementation of this program is expected to achieve the following targets: - reduction of the overall level of energy and resource consumption by industries of the city by $25-30 \%$ to the base level; 
- reduction of family expenses for payment of housing and communal services by an average of $15-25 \%$;

- reduction of energy consumption per square meter in total area of residential buildings by $20-30 \%$ to the base level;

- reduction of municipal budget expenditures in terms of utility payments for energy and resources by $15-25 \%$ to the base level;

- reduction of harmful emissions that pollute the environment in the city, by $10-15 \%$ to the base level;

- equipping with energy metering and control devices up to $100 \%$ by the time of the Program implementation;

- reducing the level of energy and resource losses to regulatory indicators;

- reducing the accident rate to 0.1 accidents and damage per $1 \mathrm{~km}$ of networks per year.

These figures are very impressive and have significant socio-economic efficiency.

Quarterly development within the boundaries of Republic street - Kholodilnaya Maurice Toreza - Malygina street is defined as a pilot area for the implementation of activities in the city of Tyumen. In this territory, in Tyumen (along with 3 other cities Apatity, Kazan and Perm) the project "Energy-efficient quarter" is being implemented. The list of priorities that are outlined by the State Program for Energy Saving and Energy Efficiency Improvement includes organization of energy accounting, replacement of incandescent lamps with energy-efficient lamps, and development of small and alternative energy.

Financing of the activities is carried out according to the following scheme:

- local budget funds - 10\%;

- funds of the regional budget $-15 \%$;

- funds of the federal budget (including the Housing and Communal Services Reform Fund)

$-20 \%$;

- credit funds of banks sent for sale.

About 13 thousand people live on the territory of the modernized quarter, the total area of residential buildings is 356 thousand $\mathrm{m} 2,45$ apartment buildings, with a total area of $356,597.7$ square meters, the number of apartments 5.178 (from 22 to 390 apartments in the house), where 12,945 people live by registration.

The houses have4 to 13 floors, the largest share (60\%) falls on 5 and 9 storey houses. Year of construction of houses varies from the 60 s to 2009 (Figure 1), the largest share is occupied by houses built in the $60-80$ s., which is $69 \%$, requiring a comprehensive overhaul.

Depending on the qualifications of buildings, the largest share falls on brick-built houses - 41 houses (91\%), 3 houses (7\%) are panel houses, 1 house (2\%) belongs to block houses (Figure 2).

Also in the district there are 5 social infrastructure facilities ( 2 schools, 1 kindergarten, 1 maternity hospital with antenatal clinic, 1 clinic), $6.6 \mathrm{~km}$ of heating networks, $13.8 \mathrm{~km}$ of electric networks, $9.4 \mathrm{~km}$ of water networks, $7.4 \mathrm{~km}$ of sewage networks. 


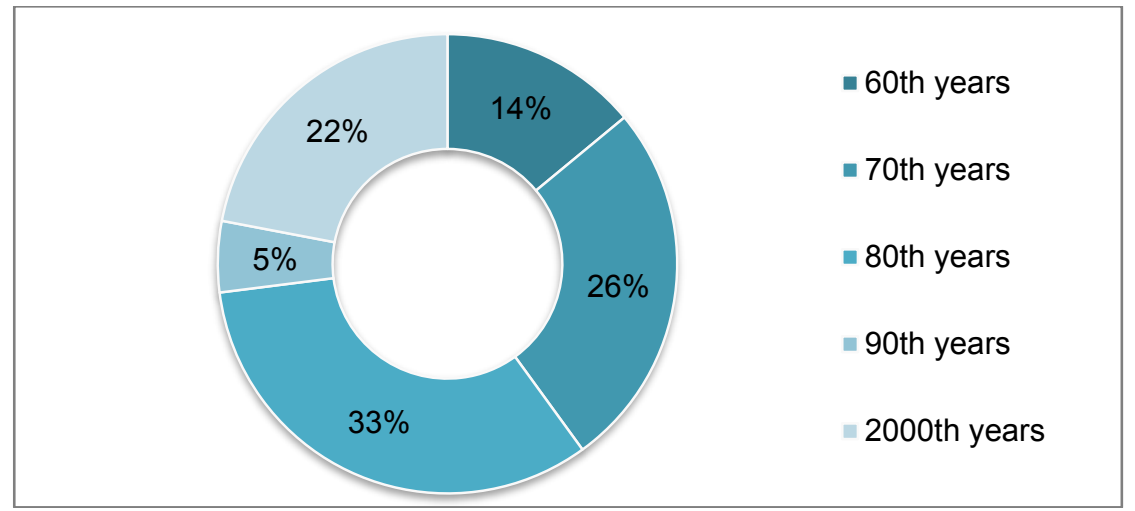

Fig. 1. The structure of apartment buildings in the pilot quarter of the city of Tyumen (by year of construction)

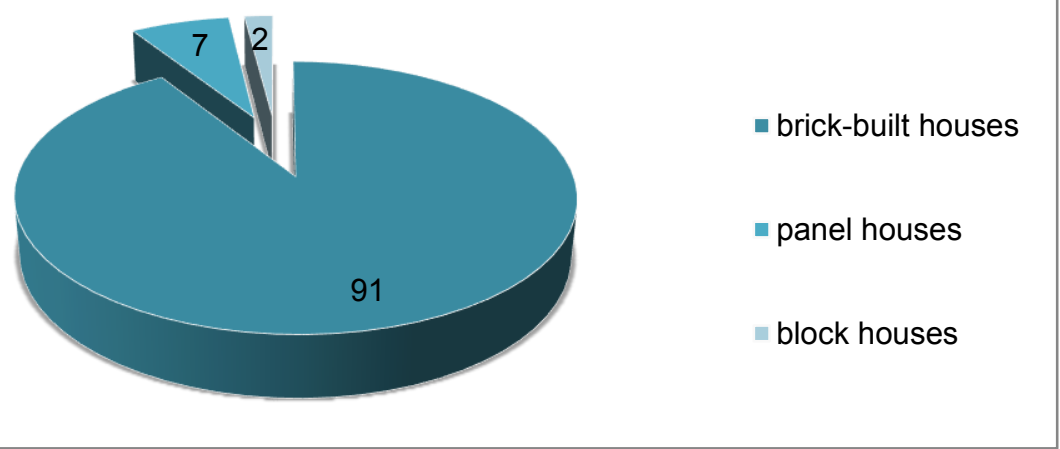

Fig. 2. The structure of apartment buildings of the pilot quarter of the city of Tyumen (on the qualification of buildings)

Losses in electric networks are about $12 \%$, in heat networks - $14 \%$, in the water supply system $-33.4 \%$. On the territory of the quarter there are 224 lighting poles. In addition, various commercial facilities are located in the quarter.

Table 1 shows the general characteristics of the engineering infrastructure of the pilot quarter.

Table 1. General characteristics of the engineering infrastructure of the pilot quarter

\begin{tabular}{|c|l|c|c|}
\hline № & \multicolumn{1}{|c|}{ Indicators } & $\begin{array}{c}\text { Units of } \\
\text { measurement }\end{array}$ & $\begin{array}{c}\text { Value of the } \\
\text { indicator }\end{array}$ \\
\hline 1. & Heating networks / including Hot water supply & $\mathrm{M}^{2}$ & $6.619 / 273$ \\
\hline 2. & Water supply networks & $\mathrm{Km}$ & 9.4 \\
\hline 3. & Wastewater networks & $\mathrm{Km}$ & 7.6 \\
\hline 4. & Power supply networks & $\mathrm{Km}$ & 13.8 \\
\hline 5. & Gas supply networks & $\mathrm{M}$ & 330.6 \\
\hline 6. & Objects of outdoor lighting, incl. & & \\
\hline 6.1. & - lamps & $\mathrm{pcs}$ & 301 \\
\hline 6.2. & - poles & $\mathrm{pcs}$ & 224 \\
\hline 6.3. & - outdoor lighting networks & $\mathrm{Km}$ & 10.7 \\
\hline 7. & Connection & $\mathrm{Km}$ & 3.396 \\
\hline
\end{tabular}


$7 \%$ of houses are equipped with collective heat meters, $4 \%$ of houses are equipped with hot water meters. The energy efficiency level of buildings, after an energy audit at 41 apartment buildings, is estimated between categories D and E (low and very low). Houses built after 2000, are estimated by energy efficiency category $\mathrm{C}$ - normal.

For the "Energy Efficient Quarter" program of the city of Tyumen, the concept of organizing measures to improve the energy efficiency of residential buildings in 3 stages was adopted. All activities are structured according to several criteria: mandatory, stages of implementation, utility systems, availability of energy-saving effect and method of accounting for capital investments in the economic justification of measures programs (Table 2,3,4).

Table 2. Systematization of the list of measures to improve the energy efficiency of a residential building (Stage 1)

\begin{tabular}{|c|c|c|c|}
\hline Stages and activities & 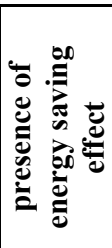 & 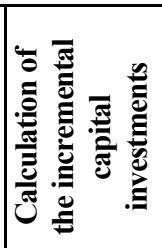 & 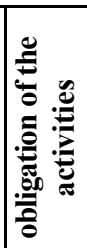 \\
\hline \multicolumn{4}{|l|}{ Heating system } \\
\hline Installation of house metering stations and automation equipment & yes & no & yes \\
\hline Flushing of indoor heating systems & yes & no & no \\
\hline Installation of energy efficient windows in common areas & yes & yes & no \\
\hline Installation of heat-reflecting screens in common areas & yes & no & no \\
\hline $\begin{array}{l}\text { Overhaul of the heating system in the basement or attic (depending on } \\
\text { the layout) }\end{array}$ & no & & no \\
\hline & \multicolumn{2}{|c|}{ Hot water supply } & \\
\hline Search and repair of plumbing with leaks & yes & no & no \\
\hline Overhaul of the HWS system in the basement (or attic), depending on the layout & yes & yes & no \\
\hline \multicolumn{4}{|l|}{ Power supply } \\
\hline Replacement of distribution switchgears with installation of two-tariff meters & yes & no & no \\
\hline Replacing incandescent bulbs in common areas & yes & yes & no \\
\hline Presence Detectors Installation & yes & no & no \\
\hline \multicolumn{4}{|l|}{ Cold water and sewage } \\
\hline Household metering of cold-water & yes & no & yes \\
\hline Search and repair of plumbing with leaks & yes & no & no \\
\hline $\begin{array}{l}\text { Overhaul of the cold water system in the basement (or attic), depending on the } \\
\text { layout }\end{array}$ & yes & yes & no \\
\hline \multicolumn{4}{|l|}{ Other activities } \\
\hline $\begin{array}{l}\text { Coloring of staircases in light colors, installation of entrance and } \\
\text { tambour doors with a door closer }\end{array}$ & no & & no \\
\hline
\end{tabular}

Table 3. Systematization of the list of measures to improve the energy efficiency of a residential building (Stage 2) 


\begin{tabular}{|l|c|c|c|}
\hline \multicolumn{1}{|c|}{ Stages and activities } & yes & no \\
\hline Heating system & yes & ye & no \\
\hline Overhaul of the heating system on the risers & yes & no & no \\
\hline Installation of balancing valves & yes & no & yes \\
\hline Installation of individual thermostatic elements on heating devices & yes & no \\
\hline \multicolumn{5}{|c|}{ Hot water supply } & yes & yes & no \\
\hline Installation of individual metering devices & yes & no & no \\
\hline Overhaul of the hot water system in risers & yes & no & yes \\
\hline \multicolumn{5}{|c|}{ Cold water supply } & yes & yes & no \\
\hline Installation of two-tariff counters
\end{tabular}

Table 4. Systematization of the list of measures to improve the energy efficiency of a residential building (Stage 3)

\begin{tabular}{|c|c|c|c|}
\hline Stages and activities & 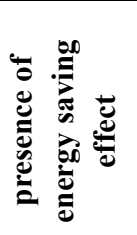 & 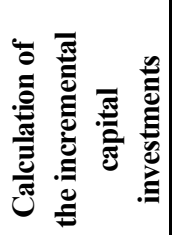 & 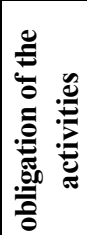 \\
\hline \multicolumn{4}{|l|}{ Heating system } \\
\hline Energy efficient windows in apartments and built-in and outbuildings & yes & yes & no \\
\hline Installation of heat-reflecting screens in apartments & yes & no & no \\
\hline Thermal insulation of floors above basements & yes & yes & no \\
\hline Roof insulation & yes & yes & no \\
\hline Wall insulation & yes & yes & no \\
\hline \multicolumn{4}{|l|}{ Power supply } \\
\hline power consumption of elevators & yes & yes & no \\
\hline Replacing incandescent bulbs in apartments & yes & yes & no \\
\hline Replacing old refrigerators and washing machines & yes & yes & no \\
\hline \multicolumn{4}{|l|}{ Gas supply } \\
\hline Installation of individual metering devices & yes & no & yes \\
\hline
\end{tabular}

At the first stage, only relatively low-cost measures are implemented in public places. Some of them are capital repair measures that do not give a direct energy-saving effect, but are important as a necessary condition for obtaining an energy-saving effect from other measures. The costs of such measures are taken into account in the cost estimates, but are 
not taken into account when calculating the payback period of energy efficiency measures. Part of the measures can be implemented by traditional technology or through the use of energy-saving technologies (for example, replacement of windows and lamps in public places). Therefore, when calculating the payback period of these measures, the concept of incremental capital investments is used, that is, only the difference between the cost of a traditional and an energy-efficient solution is taken into account.

At the second stage, measures related to the installation of individual metering and regulation devices are implemented. At the third stage state support is provided to the population for the purchase and installation of energy-saving window blocks, heating devices and energy-efficient lighting systems and household appliances through the provision of subsidies to the population. At the same stage, it is possible to implement more expensive measures to insulate the building.

Some of the measures in this list are mandatory: their implementation is necessary in accordance with the requirements of the Federal Law of November 23, 2009 No. 261 "On Energy Saving and Energy Efficiency Improvement and Amendments to Certain Legislative Acts of the Russian Federation". These include measures to equip apartment buildings with collective (house-wide) metering devices for used water, thermal energy, electric energy, as well as individual and common (for a communal apartment) metering devices for used water, natural gas, and electric energy. These metering devices must be installed and put into operation before January 1, 2012.

\section{Results}

As a test, proving the economic feasibility of energy-saving measures, a set of measures that can be implemented in a residential building in Tyumen in the pilot area of the program is presented.

The building was built according to a standard design in 1972 and has 5 floors, 6 entrances, 99 apartments, 210 rooms, and the number of residents is 200 . Engineering and technical communications are located in the unheated basement. The building has a warm attic where air flows from the ventilation ducts (Table 5).

Table 5. General characteristics of a residential building

\begin{tabular}{|c|l|c|c|}
\hline № & \multicolumn{1}{|c|}{ Indicators } & $\begin{array}{c}\text { Unit of } \\
\text { measurement }\end{array}$ & Value of indicators \\
\hline 1 & Year of construction & - & 1972 \\
\hline 3 & Floors & - & 5 \\
\hline 4 & Number of entrances & - & 6 \\
\hline 5 & Number of apartments in the building & - & 99 \\
\hline 6 & Number of inhabitants & people & 200 \\
\hline 7 & Type of roof & - & pitched roof \\
\hline 8 & Heated volume (in the project) & $\mathrm{m}^{3}$ & 17421,0 \\
\hline 9 & Total area of the building & $\mathrm{m}^{2}$ & 5142,9 \\
\hline 10 & Heated area & $\mathrm{m}^{2}$ & 5142,9 \\
\hline 11 & Total area of residential premises & $\mathrm{m}^{2}$ & 4417,3 \\
\hline 13 & Basement & - & technical underground \\
\hline 14 & Light conduction & units & 434 \\
\cline { 2 - 4 } & Window & units & 334 \\
\cline { 2 - 4 } & including double glazing & units & 70 \\
\cline { 2 - 4 } & ordinary & units & 264 \\
\cline { 2 - 4 } & Balcony doors & units & 100 \\
\cline { 2 - 4 } & including double glazing & units & 24 \\
\hline
\end{tabular}




\begin{tabular}{|c|c|c|c|}
\hline & ordinary & units & 76 \\
\hline 15 & Number of entrance doors (entrance groups) & units & 6 \\
\hline \multirow[t]{6}{*}{16} & Area of building envelope, including: & $\mathrm{M}^{2}$ & 3100 \\
\hline & the walls & $\mathrm{M}^{2}$ & 776,8 \\
\hline & windows and balcony doors & $\mathrm{M}^{2}$ & 701,2 \\
\hline & entrance doors & $\mathrm{M}^{2}$ & 18 \\
\hline & Overlap 1st floor & $\mathrm{M}^{2}$ & 0 \\
\hline & Overlap & $\mathrm{M}^{2}$ & 1604 \\
\hline 17 & $\begin{array}{l}\text { Electricity metering device for lighting of } \\
\text { common areas }\end{array}$ & have / no & have \\
\hline 18 & $\begin{array}{l}\text { Electricity metering device for the maintenance } \\
\text { of elevators }\end{array}$ & have / no & no \\
\hline 19 & Electricity metering device for electric stoves & have / no & no \\
\hline 20 & Apartment electricity metering devices & units & 101 \\
\hline 21 & Electricity metering devices of tenants & units & 1 \\
\hline 22 & $\begin{array}{l}\text { House site of the commercial accounting of } \\
\text { consumption of thermal electricity }\end{array}$ & have / no & no \\
\hline 23 & $\begin{array}{l}\text { House site of the commercial accounting of } \\
\text { consumption of water }\end{array}$ & have / no & no \\
\hline 24 & Domestic hot water metering devices & units & 0 \\
\hline 26 & $\begin{array}{l}\text { Means of regulating heat consumption in general } \\
\text { for a building }\end{array}$ & $\begin{array}{c}\text { type and } \\
\text { availability }\end{array}$ & no \\
\hline 27 & $\begin{array}{l}\text { Means for regulating heat consumption in } \\
\text { apartments }\end{array}$ & $\begin{array}{l}\text { type and } \\
\text { availability }\end{array}$ & no \\
\hline 28 & Dates of the last major overhaul & & $18.05 .2007-22.08 .2007$ \\
\hline 29 & Characteristics and type of work on the overhaul & & $\begin{array}{l}\text { heating, hot and cold } \\
\text { water supply, sewage }\end{array}$ \\
\hline
\end{tabular}

In addition to the mandatory measures of the Federal Law "On Energy Saving and Energy Efficiency Improvement", it also requires that management companies develop proposals for energy saving and energy efficiency measures that can be implemented in an apartment building, with an indication of the cost of their implementation, the volume of the expected reduction of the energy resources used and the payback period of the proposed measures and communicate to the owners of premises in an apartment building at least once a year.

Such a list of measures is given in Table $6,7,8$ with an indication of energy savings, financial costs and estimates of the payback period.

Table 6. The list of measures to improve the energy efficiency of the building (Stage 1)

\begin{tabular}{|c|c|c|c|c|c|c|c|}
\hline \multirow[t]{2}{*}{ Content of measures } & \multirow[t]{2}{*}{ Units } & \multirow[t]{2}{*}{ Total cost } & \multirow[t]{2}{*}{$\begin{array}{l}\text { Energy } \\
\text { Efficiency } \\
\text { Costs }\end{array}$} & \multirow[t]{2}{*}{$\begin{array}{l}\text { Expected } \\
\text { annual } \\
\text { economic } \\
\text { effect }\end{array}$} & \multicolumn{3}{|c|}{$\begin{array}{l}\text { Schedule of } \\
\text { implementation of } \\
\text { measures to improve } \\
\text { energy efficiency of } \\
\text { the building, years }\end{array}$} \\
\hline & & & & & 2016 & 2017 & 2018 \\
\hline \multicolumn{8}{|c|}{ Stage 1} \\
\hline $\begin{array}{l}\text { Heat point with metering } \\
\text { and regulation }\end{array}$ & $\begin{array}{l}\text { Heat } \\
\text { point }\end{array}$ & 19166.67 & 16805.56 & 1715.57 & + & & \\
\hline $\begin{array}{l}\text { Washing of house heating } \\
\text { networks }\end{array}$ & systems & 1388.89 & 0 & 19.64 & + & & \\
\hline $\begin{array}{l}\text { Installing screens behind } \\
\text { radiators in common areas }\end{array}$ & screens & 100 & 100 & 19.64 & + & & \\
\hline $\begin{array}{l}\text { Installation of energy } \\
\text { efficient windows in } \\
\text { common areas }\end{array}$ & $\mathrm{M}^{2}$ & 6750 & 2375 & 115.32 & + & & \\
\hline
\end{tabular}




\begin{tabular}{|c|c|c|c|c|c|c|c|}
\hline $\begin{array}{l}\text { House node for cold-water } \\
\text { metering }\end{array}$ & nodes & 504.44 & 504.44 & 1552.32 & + & & \\
\hline $\begin{array}{l}\text { Search and repair of } \\
\text { plumbing with leaks }\end{array}$ & building & 55.56 & 555.56 & 543.56 & + & & \\
\hline $\begin{array}{l}\text { Replacing incandescent } \\
\text { lamps in public places and } \\
\text { in outdoor lighting with } \\
\text { energy-saving compact } \\
\text { fluorescent lamps }\end{array}$ & lamps & 120.83 & 80.56 & 80.72 & + & & \\
\hline $\begin{array}{l}\text { Installation of presence } \\
\text { sensors in common areas }\end{array}$ & sensors & 120.83 & 120.83 & 161.43 & + & & \\
\hline $\begin{array}{l}\text { Replacement of distribution } \\
\text { switchgears with installation of } \\
\text { two-tariff meters }\end{array}$ & units & 309.32 & 309.32 & 40.11 & + & & \\
\hline $\begin{array}{l}\text { Coloring of staircases in } \\
\text { light colors, installing } \\
\text { entrance and vestibule } \\
\text { doors with a door closer }\end{array}$ & building & 19970.07 & 0 & 0 & + & & \\
\hline $\begin{array}{l}\text { Overhaul of electrical } \\
\text { equipment }\end{array}$ & building & 20993.86 & 0 & 0 & + & & \\
\hline Total stage 1 & & 69480.47 & 20851.26 & 4248.32 & & & \\
\hline
\end{tabular}

Table 7. The list of measures to improve the energy efficiency of the building (Stage 2)

\begin{tabular}{|c|c|c|c|c|c|c|c|}
\hline \multirow[t]{2}{*}{ Content of measures } & \multirow[t]{2}{*}{ Units } & \multirow[t]{2}{*}{ Total cost } & \multirow[t]{2}{*}{$\begin{array}{l}\text { Energy } \\
\text { Efficiency } \\
\text { Costs }\end{array}$} & \multirow[t]{2}{*}{$\begin{array}{l}\text { Expected } \\
\text { annual } \\
\text { economic } \\
\text { effect }\end{array}$} & \multicolumn{3}{|c|}{$\begin{array}{c}\text { Schedule of } \\
\text { implementation of } \\
\text { measures to improve } \\
\text { energy efficiency of } \\
\text { the building, years }\end{array}$} \\
\hline & & & & & 2016 & 2017 & 2018 \\
\hline $\begin{array}{l}\text { Installation of individual } \\
\text { two-tariff electricity meters }\end{array}$ & $\begin{array}{c}\text { apartme } \\
\text { nts }\end{array}$ & 3296.53 & 3296.53 & 640.71 & + & & \\
\hline $\begin{array}{l}\text { Installation of individual } \\
\text { hot water metering devices }\end{array}$ & $\begin{array}{c}\text { apartme } \\
\text { nts }\end{array}$ & 2337.50 & 2337.50 & 175.31 & + & & \\
\hline $\begin{array}{l}\text { Installation of individual } \\
\text { cold water metering devices }\end{array}$ & $\begin{array}{c}\text { apartme } \\
\text { nts }\end{array}$ & 2337.50 & 2337.50 & 543.22 & + & & \\
\hline $\begin{array}{l}\text { Installation of individual } \\
\text { thermostatic elements on } \\
\text { heating devices }\end{array}$ & units & 1636.11 & 1636.11 & 98.61 & + & & \\
\hline $\begin{array}{l}\text { Installation of balancing } \\
\text { valves on the main heating } \\
\text { pipelines }\end{array}$ & units & 800 & 800 & 59 & + & & \\
\hline $\begin{array}{l}\text { Overhaul of the heating } \\
\text { system on the risers }\end{array}$ & $\mathrm{M}^{2}$ & 1857.19 & 371.43 & 19.64 & & + & \\
\hline $\begin{array}{l}\text { Overhaul of the hot water } \\
\text { system on risers }\end{array}$ & $\mathbf{M}^{2}$ & 2071.49 & 414.29 & 87.61 & & + & \\
\hline $\begin{array}{l}\text { Overhaul of the cold water } \\
\text { system on risers }\end{array}$ & $\mathbf{M}^{2}$ & 1142.89 & 228.57 & 386.83 & & + & \\
\hline Total stage 2 & & 15479,21 & 11421.93 & 2010.94 & & & \\
\hline
\end{tabular}

Table 8. The list of measures to improve the energy efficiency of the building

\begin{tabular}{|c|l|l|l|c|c|}
\hline Content of measures & Units & Total cost & $\begin{array}{c}\text { Energy } \\
\text { Efficienc } \\
\text { y Costs }\end{array}$ & $\begin{array}{c}\text { Expected } \\
\text { annual } \\
\text { economic } \\
\text { effect }\end{array}$ & $\begin{array}{c}\text { Schedule of } \\
\text { implementation of } \\
\text { measures to } \\
\text { improve energy } \\
\text { efficiency of the }\end{array}$ \\
\hline
\end{tabular}




\begin{tabular}{|c|c|c|c|c|c|c|c|}
\hline & & & & & \multicolumn{3}{|c|}{ building, years } \\
\hline & & & & & 2016 & 2017 & 2018 \\
\hline $\begin{array}{l}\text { Installation of energy } \\
\text { efficient windows in } \\
\text { apartments }\end{array}$ & windows & 36666.67 & 23833.33 & 426.57 & & + & + \\
\hline $\begin{array}{l}\text { Installing screens behind } \\
\text { radiators in apartments }\end{array}$ & screens & 1391.67 & 1391.67 & 98.38 & & + & + \\
\hline $\begin{array}{l}\text { Replacing incandescent } \\
\text { bulbs in apartments }\end{array}$ & bulbs & 360.42 & 360.42 & 393.24 & & + & + \\
\hline Replacing old refrigerators & units & 194.44 & 194.44 & 18.10 & & + & + \\
\hline Total stage 3 & & 3861.19 & 25779.86 & 936.28 & & + & + \\
\hline Total for all stages & & 123572.88 & 58053.06 & 7195.54 & & + & + \\
\hline Energy Saving Activities & & 123572.88 & 58053.06 & 7195.54 & & + & + \\
\hline $\begin{array}{l}\text { Peak power release from } \\
\text { daily zoning }\end{array}$ & kw & 0 & 0 & 252.50 & & + & + \\
\hline $\begin{array}{l}\text { Peak power release from } \\
\text { increased lighting efficiency }\end{array}$ & kw & 0 & 0 & 252.50 & & + & + \\
\hline $\begin{array}{l}\text { Peak power release from } \\
\text { refrigerator replacement }\end{array}$ & kw & 0 & 0 & 16.83 & & + & + \\
\hline $\begin{array}{l}\text { Activities not included in } \\
\text { the program }\end{array}$ & & 0 & 30722.22 & 452.54 & & + & + \\
\hline $\begin{array}{l}\text { Repair of windows with the } \\
\text { installation of heat } \\
\text { reflecting film }\end{array}$ & windows & 3666.67 & 3666.67 & 213.29 & & + & + \\
\hline Wall insulation & $\mathrm{M}^{2}$ & 26972.22 & 26972.22 & 236.18 & & & \\
\hline
\end{tabular}

Payback periods are estimated only for energy saving measures. When calculating payback periods, the concept of incremental capital investments is used, that is, only the difference between the cost of a traditional and energy efficient solution is taken into account (Tables $6,7,8)$. In the calculations of payback periods, prices and tariffs for utility resources for 2018 are used.

The approximate project implementation schedule is shown in Table 5. It is drawn up in accordance with the three-stage project implementation scheme so that all costs, including capital repairs, that do not have the effect of energy saving, still pay off due to the savings obtained through the implementation of other measures.

At the first stage, the ESCO refinances $90 \%$ of the savings to the project, which reduces the need for borrowed funds. The loan amount itself is equal to 69043 euros. It was obtained taking into account the possibility of financing the project for 10 years with a grace period of 1 year at $15 \%$ per annum with quarterly payment. The interest rate on loans for ESCOs is subsidized at the expense of budget funds. These expenses are equal to 54784 euros.

At the second stage, targeted grants are allocated for the implementation of measures for energy saving and energy efficiency in the premises of the owners (installation of individual metering devices). They are represented by the MC, HOA after reaching the targets of the 1st stage. The budget expenditures for grants are estimated at 14679 euros.

After reaching the MC, HOA, HBC targets of the second stage in the third stage, the interest rate is subsidized at the expense of budget funds to the population on the basis that the loan is provided at $15 \%$ for three years. In this case, the budget accounts for about $44 \%$ of all costs for the purchase of equipment and the repayment of interest on loans for the 
population. Budget expenditures for subsidizing interest rates for the population are 11583 rubles.

Tables 6,7,8 list and schedule energy efficiency measures for the building at ul. Karskaya 24.

The expenses of the population are equal to 38613.2 euros, and the expenses of the ESCO - 58396.5 euros. The budget share in the project costs depends on the interest rate on the loan. Estimation of savings made under the assumption of the growth of tariffs for utilities by $10 \%$ per year.

The approximate financing scheme of the project is shown in Table 6 . The total costs of the project are equal to 123272.8 euros, and taking into account interest payments on the loan - 178057 euros.

To finance a project to develop energy efficiency measures for a residential building, the following funds are used: own funds of the energy service company (ESCO), budget grants and subsidized interest rates for the population, household expenses and credit [5].

Project financing will take 10 years.

Table 9. Project Financial Flows

\begin{tabular}{|c|c|c|c|c|}
\hline Year & Total expenses & Population expenses & $\begin{array}{c}\text { Accumulated net } \\
\text { income }\end{array}$ & $\begin{array}{c}\text { Budget } \\
\text { expenditures }\end{array}$ \\
\hline 2016 & 77480.9 & 0.0 & 2670.3 & 11796.4 \\
\hline 2017 & 45791.9 & 38613.2 & 3494.4 & 21180.8 \\
\hline 2018 & 5909.4 & 12923.3 & 5909.4 & 12923.3 \\
\hline 2019 & 11924.2 & 11772.6 & 11924.2 & 11772.6 \\
\hline 2020 & 21609.1 & 6760.5 & 21609.1 & 6760.5 \\
\hline 2021 & 35331.2 & 5609.8 & 35331.2 & 5609.8 \\
\hline 2022 & 53494.0 & 4459.1 & 53494.0 & 4459.1 \\
\hline 2023 & 76541.7 & 3308.3 & 76541.7 & 3308.3 \\
\hline 2024 & 104961.7 & 2157.6 & 104961.7 & 2157.6 \\
\hline 2025 & 139294.7 & 1006.9 & 139294.7 & 1006.9 \\
\hline 2026 & 191635.6 & 71.9 & 191635.6 & 71.9 \\
\hline
\end{tabular}

\section{Conclusions}

Energy saving is currently the most important direction of the energy policy of the country. Energy saving is important for socio-economic development and contributes to the improvement of living conditions, increasing the comfort of housing, improving the means of transportation, facilitating working conditions.

It should be noted that it is important to save not only in the house itself, but also in each apartment. Energy-saving activities in the apartment are: replacement of incandescent lamps with energy-saving lamps; installation of thermostats on radiators; installation of metering devices for cold and hot water supply systems, and, if possible, for heating and gas systems; when replacing window units installation of triple-glazed windows; buying household appliances with less power consumption; installation of residential two-tariff meters; measures for the insulation of window openings and entrance doors.

World experience shows that there is a real possibility of reducing energy consumption by 2 times. However, to achieve such a result, long-term joint efforts of scientists, architects, designers, heat specialists, power engineers, construction industry specialists, 
managers of building complexes and housing and public utilities are needed, step by step, successively increasing energy efficiency each in its own area.

\section{References}

1. V. V. Markin, Strategic management of energy efficiency in the region of St. Petersburg State University of Economics and Technology (St. Petersburg, 2008)

2. I. S. Shapovalov, Energy Saving, 1, 56-60 (2009)

3. Yu. A. Matrosov, Energy saving in buildings. The problem and how to solve it (NIISF, Moscow, 2008)

4. I. A. Bashmakov, Energy Saving, 8, 40-51 (2009)

5. V. V. Markin, Management of innovative development of the energy efficiency system in the region (Info-da, St. Petersburg, 2007) 